\title{
Policy Autonomy, CoOrdination Or Harmonization in the Persistently Heterogeneous EUROPEAN UNION?
}

\section{Luděk Kouba $^{1}$, Michal Mádr ${ }^{2}$, Danuše Nerudová ${ }^{3}$, Petr Rozmahel ${ }^{4}$}

\begin{abstract}
Within the context of the continuing integration process in Europe, this paper addresses the question of whether policies in the EU should head towards autonomy, coordination or harmonization. Taking the path dependence effect into account, it is the authors' opinion that Europe has gone too far in its integration process to be able to continue with policies being fully under the competences of individual member countries. However, the habitual question still arises: does fiscal policy need to be harmonized to a level comparable to monetary policy as these two policies, necessarily, complement each other? This paper argues that it does not. There are three main arguments discussed. Firstly, the authors build on the theory of fiscal federalism. Secondly, there are significantly different regimes of welfare states and extents of social policies among European countries, which strongly determine the character of public finance. And thirdly, the tax systems across Europe are also highly divergent, with many features of continuing tax competition.
\end{abstract}

\section{Keywords}

European Union, Fiscal Policy, Heterogeneity, Policy Coordination, Policy Harmonization

\footnotetext{
${ }^{1}$ Department of Economics, Faculty of Business and Economics, Mendel University in Brno, Zemědělská 1, 61300 Brno, Czech Republic. E-mail: kouba@mendelu.cz.

2 Department of Economics, Faculty of Business and Economics, Mendel University in Brno, Zemědělská 1, 61300 Brno, Czech Republic. E-mail: michal.madr@mendelu.cz.

${ }^{3}$ Department of Accounting and Taxes, Faculty of Business and Economics, Mendel University in Brno, Zemědělská 1, 61300 Brno, Czech Republic. E-mail: danuse.nerudova@mendelu.cz.

${ }^{4}$ Department of Economics, Faculty of Business and Economics, Mendel University in Brno, Zemědělská 1, 61300 Brno, Czech Republic. E-mail: petr.rozmahel@mendelu.cz.
} 


\section{Introduction}

The European integration process continues. Europe is still heterogeneous. These are the two truths that are the initial subjects for discussion in this paper. Natural intuition says that these two statements are contradictory rather than complementary. Therefore, the following question arises: should European countries head towards more autonomous or more unified policies? Because of challenges resulting from, in particular, the globalization of the world economy and ageing populations in developed countries, discussion on the level of policy cooperation in the European Union has been highly relevant for at least two decades. Furthermore, today's migration crisis has added a new, almost existential, dimension to this discussion.

In accord with the Seventh Framework Programme Project, "Wealth, Welfare and Work for Europe" (see Acknowledgments below), this paper examines whether a governance structure with central authority and with centralized functions resulting from the harmonization process, such as in the case of the European and Monetary Union (EMU), is the best way to achieve further economic integration. Regarding fiscal policy, such a harmonization process would likely imply the formation of a fiscal union (1) with centralized fiscal functions. Alternative scenarios could either be largely autonomous policies (2) or the process of policy coordination (3) leading to a government structure with implemented co-ordination mechanisms.

When discussing these matters, even critics of the European integration process should take the concept of path dependence into account. One of the most widely used concepts in contemporary social science (Rixen and Viola, 2009), explains how the decisions faced for any given circumstance are limited by the decisions made in the past, even though past circumstances may no longer be relevant. The best-known example of the path dependence effect is the QWERTY layout for typewriters (David, 1985). North (1990), the proponent of new institutional economics, made a famous parallel between the original field of technologies and the area of economic institutions. Later, Pierson (2004) imported the concept of path dependence into political science. Increasing returns are typical for political institutions since they significantly affect actors' expectations, and therefore decrease the transaction costs associated with coordinating behaviour. In addition, the establishment process of institutions is usually related to high costs: institutions create incentives for their maintenance and therefore the system evolves along a particular path that has been "locked in" (Arthur, 1989).

The European integration process is a characteristic example of an institutional "lockin", which makes an essential reverse almost impossible or highly unlikely. Moreover, this generally "locked-in" integration process is further embodied into vast monetary unification, where the costs of the potential failure of the EMU would be astronomically high. Around $€ 270$ billion has been paid by the European Financial Stability Facility, the European Central Bank and the International Monetary Fund to Greece (Financial Times, 2015). For comparison, this is twice the size of the EU budget. If Greece stopped paying off its debts, the potential losses for the main creditors among European countries would be 56 billion euro for Germany, 42 billion euro for France, 37 billion euro for Italy 
and 25 billion euro for Spain (Business Insider, 2015). Not taking into account the extent of financial help to the other affected Eurozone countries, it is apparent that European politicians have been determined to save the Eurozone under (almost) any circumstances. Therefore, this paper does not consider a reverse to fully autonomous economic policies in Europe to be realistic.

However, what does the fact of the continuing heterogeneity in Europe bring to the discussion? Is the concept of the harmonization of economic policies often proposed in the EU really rational? Moreover, what is the lesson to be learned from the inclusion of Central and Eastern European countries?

The purpose of this paper is to discuss these questions, focusing on the area of fiscal policies. The paper found its inspiration in, among others, papers by Aiginger (2013), Gabrisch and Staehr (2014), Rozmahel, Grochová and Litzman (2014), and van Aarle (2013). Furthermore, this paper builds on the final thesis of Rozmahel, Kouba, Grochová and Najman (2013): "Instead of harmonization, we call for better coordination and joint responsibility in the fiscal area, and more generally in terms of policies and institutions in the European Union." This statement implies that we distinguish between the coordination of less or more autonomous national policies and comprehensive harmonization towards unified EU policies.

Naturally, the establishment of the common currency in the EU, as the result of deep harmonization in the monetary policy area, is an unambiguous precedent with many consequences (e.g. Darvas and Wolff, 2013). First of all, the habitual question still arises in literature. Does fiscal policy need to be harmonized to a comparable level as these two policies, necessarily, complement each other? On the one hand, there are voices for creating a fiscal union as an inevitable complement to the common monetary union. The wide European debate on the pros and cons of a fiscal union, as well as a political and banking union, in relation with the sustainability of the monetary union, is presented by Allen, Carletti and Gray (2013). Also, Beetsma and Giuliodori (2010) and van Aarle (2013) discuss selected aspects of various fiscal integration strategies in the EU. On the other hand, as stated by, for instance, Burda and Wyplosz (2012) or De Grauwe (2012), there are strong arguments for keeping a certain level of fiscal autonomy at national levels if there is no political will to pursue any stabilisation system of fiscal transfers at the supra-national level of the EU. The path of fiscal federalism, allowing inter-national or inter-regional fiscal transfers or autonomous fiscal policy, belongs among the adjustment mechanisms to be used in the event of the occurrence of asymmetric shocks, as follows from traditional as well as "New" optimum currency areas theory (Mongelli, 2002). Arguments from the theory of fiscal federalism are discussed more deeply in section III. In addition, other arguments for coordination instead of harmonization in the fiscal area are the highly heterogeneous national tax systems (Machová and Kotlán, 2013) and also the significantly different regimes and the extent of welfare states among European countries.

The paper's understanding of the key terms, such as harmonization, coordination, and autonomy, is elaborated in section II. Section III supports the authors' line of reasoning against deep harmonization and the centralization of fiscal policy in the EU with arguments from the theory of fiscal federalism. Next, the main section - IV. "Coordination 
vs. harmonization within the context of fiscal policy integration in Europe" - recaps the persistent heterogeneity level in the EU, including the impact of the integration of CEE countries. It then discusses the potential pros and cons of autonomy, coordination and harmonization tendencies in European fiscal and tax policies. Section V summarizes the main ideas and provides some policy-relevant conclusions.

\section{Coordination and harmonization: complementary or diverse concepts?}

Generally, one can distinguish between autonomous policies, which can be accompanied (but not necessarily) by direct competition among individual countries, on the one hand, and full unification, which in certain areas is called harmonization, on the other. Nonetheless, because of the achieved level of integration in Europe, this paper labels rigorously autonomous policies at a national level as being highly unlikely. Therefore, one should ask about the relationship between the terms coordination and harmonization. Analysing the current literature, we can identify two views on the relation between harmonization and the coordination of particular policies.

The first view understands both terms as being close contemporary processes or directly as synonyms, i.e., as opposites to the principles of subsidiarity, autonomy policies and competition among countries, e.g., in the tax area. This kind of argumentation for coordination-harmonization in the EU (EMU) is stated, e.g., in Clement-Wilz (2014), Gabrisch (2011), Giurescu and Vasilescu (2006), Köhler-Töglhofer (2011), and Roman and Bilan (2008).

Starting with the papers dealing with coordination of economic policies in a broader context, Roman and Bilan (2008, p. 509) emphasize the importance of broad coordination for successful development in the EU: "Realizing an efficient coordination of economic policies represents a necessary condition for achieving a stable and durable economic growth within the Union and ... increasing cooperation (dialogue) between authorities." Giurescu and Vasilescu (2006) consider the insufficient coordination of the economic policies as a macroeconomic risk factor for European integration. According to them, the risk factor "consists in the heterogeneity of member states' economies, the taxation strategies and the insufficient coordination between the budget policies and the monetary policy." Gabrisch (2011, p. 69), who derives the necessity for coordination from current account imbalances, speaks also about macroeconomic coordination, which "needs a clear identification of union-wide employment goals, and the establishment of a high level institution (High Representative for Economic Policy) responsible for coordination following these objectives." According to Clement-Wilz (2014, p. 99), current anti-crisis measures in the EU strengthen (and coordinate) fiscal discipline and the coordination of other economic policies as well.

While the previous contributions deal with the coordination of economic policies in general, other authors, within the discussion on policy coordination, are more specifically talking about labour market policy (Rantala, 2003; Stockhammer, 2008), environmental policy (Straume, 2003) or harmonization of criminal law (Calderoni, 2010). 
Regarding the term harmonization itself, it is most frequently used in the areas of tax policy and accounting. Furthermore, harmonization is typically discussed as the opposite to tax competition. While Bénassy-Quéré, Trannoy and Wolff (2014), Fernández-deCórdoba and Torres (2012), Garcia, Pabsdorf and Mihi-Ramirez (2013) and Gullo (2013) argue for tax harmonization, Oates (2001) and Schäfer (2006) support the principle of tax subsidiarity. It is this paper's opinion that, in present-day Europe, tax competition still prevails in comparison to tax harmonization. On the other hand, the introduction of united accounting standards (e.g., International Financial Reporting Standards - IFRS) is an example of the implementation of meaningful and successful harmonization. In this sense, Samuels and Piper (1985, pp. 56-57) define the international harmonization of accounting as "the attempt to bring together different systems. It is the process of blending and combining various practices into an orderly structure, which produces a synergistic result”. Nowadays, e.g., Kapić and Bašić (2013) and Wang (2014) evaluate that IFRS improve the quality of financial statements and the comparability of the data published by enterprises, etc. For more details from the relevant area of tax policy and accounting, see section "Tax systems and policy in the EU: harmonization, coordination and competition". The second view, on the contrary, distinguishes coordination from harmonization. The differences are also discussed, mainly with reference to the example of the tax area, by, for instance, Faria (1995), O'Shea (2007), and Shikwati (2012). Our understanding of the difference between coordination and harmonization is very close to that of Shikwati (2012) who, among others, points out the question of realism: "we need to pursue 'tax coordination' rather than 'tax harmonization' as 'harmonization' is mostly focused on achieving same tax rates, which is not realistic even in a common market. 'Tax coordination' is focused on application of common rules and principles". While Shikwati's recommendations are focused on African integration processes (ECOWAS), O'Shea (2007, p. 814) comes to a similar conclusion when discussing the context of EU countries: "the member states (EU) will continue to try to find solutions that meet their national interests and will comply with their EC Treaty obligations, but it is unlikely that such solutions will be found at the Community level".

The distinctions between both concepts can also be demonstrated while using the example of law, namely environmental legislature, see Faure (2000, p. 181).

Finally, the theme of subsidiarity is another important point within the discussion on the future of the EU policies, e.g. Bird and Ebel (2007), Gelauff, Grillo and Lejour (2008) and Lighian (2012). Schäfer (2006, p. 249) argues that "The key vision should not be a Europe of harmonised equalness, but a Europe of subsidiarity, of plurality in differentiation”. From our point of view, the principle of subsidiarity lies somewhere between autonomy and coordination on the related scale (see Figure 1), in other words, it is compatible with both of these approaches to economic policies in integrating groupings.

This paper discusses, in particular, two approaches to the policies within an integration process: harmonization and coordination. Within this discussion, we apply the second mentioned view - a differentiation between the approach of coordination and harmonization. While coordination is a process maintaining certain levels of autonomy, harmonization 
tends to lead to a full unification or centralization of particular policies. The differences are summarised in the following figure.

Figure 1: The scale of the policy approaches in the integration groupings

Integration
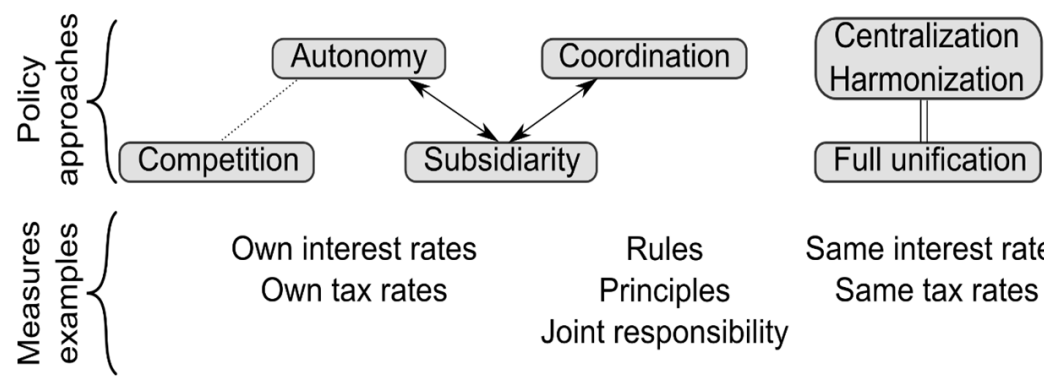

Own interest rates

Own tax rates

Rules
Principles
Joint responsibility

Same interest rates

Same tax rates

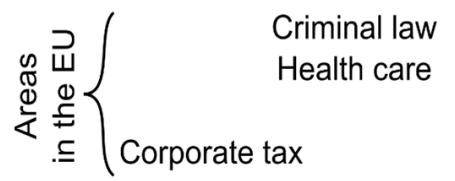

Foreign policy

Monetary policy

Labour law

SGP

Customs

Monetary Union

Source: Authors

\section{Coordination vs. harmonization: reflections in the theory of fiscal federalism}

This paper's approach, of differentiation between policy coordination and harmonization, can be more deeply supported through the use of arguments from the theory of fiscal federalism. Within the context of the interventionist 1950s, Musgrave (1959) focused on the economic role of the public sector - his well-known triad of stabilisation, distribution and allocation - solely with single-level governance. Oates $(1968,1972)$ strived to apply Musgrave's typology of public finance roles in a multi-level governance model labelled fiscal federalism. Fiscal federalism seeks the best level of governance to perform public finance functions in an economy, i.e., provide public goods and collect budget revenues. Oates simplified it into a two-level public administration model: centre vs. regions, e.g., the German federal government vs. länders, the US federal government vs. federal states, or, in this paper's case, the EU vs. member states.

According to Oates $(1968,1972)$, the stabilization function should be kept at a central level. Regions are not usually able to react efficiently to economic decline, e.g., regional government cannot perform currency devaluation. In addition to that, fiscal policy instruments only have limited impact compared to their implementation at the central level, due to the openness of current economies (partial outflow of increased expenditures out of the region to foreign producers in the form of increased imports).

Similarly, Oates also recommends centralisation in the case of the redistribution function, which is based on the assumption of mobile production factors. If the regional government 
in a prosperous region seeks to intensify a redistribution function through progressive taxation and vast social transfers, it is probable that people will start to migrate to a region without progressive taxes. On the contrary, high social transfers will cause an inflow of low-income population groups (one can observe this in the current EU). Moreover, high taxation of capital can result in the leaving of investors, which can further weaken the local economy. Given the fact that particular production factors can have diverse mobility at a regional and national level, various levels of government should use differing types of taxes (e.g., property tax or VAT at a regional level).

Finally, the allocation function should be, according to Oates, decentralised. The preferences of public service users are non-homogenous; therefore, public services can be demanded in various quantities and qualities across particular regions. It is assumed that lower levels of governance have a better understanding of people's preferences, since these are in closer contact with their citizens and have a better knowledge of local conditions (conditions of roads, transportation, environment, etc.).

Oates' approach therefore meant a reversal in the understanding of government roles.

The contemporary literature usually distinguishes two evolutionary stages of fiscal federalism: first generation and second generation. There is no strict border between them; however, the most characteristic difference of the second generation lies in its focus on the growth effects of fiscal decentralization instead of equity effects, which are typical for the first generation. For instance, Weingast (2009, p. 280) says that models belonging to the first generation of fiscal federalism stress the importance of intergovernmental transfers in order to balance regional disparities, whereas the models of the second generation emphasize the role of tax incentives. Regional and local governments are motivated to efficiently allocate resources and provide market-enhancing public goods when they get a higher share of tax revenues. Furthermore, Weingast (2009, p. 279) remarks that, while the first generation is a rather normative approach (what we should do), the second generation is a more positive approach (what we can do under given conditions). Considering contemporary EU policies, Tanzi (2008) points out two omitted aspects. Firstly, he sees a need to anchor fiscal federalism theories in historic time (see the reference to North's concept of path dependence in the Introduction). Secondly, he emphasizes the fact that strong supranational institutions exist in the globalized world of the 21 st century. Moreover, these global institutions also play a significant role in the area of public finance. Tanzi even concludes (2008, p. 711): "there is need for theories that deal with the role and the form of 'global governments'."

Before each application of the theory of fiscal federalism in the context of the EU, one has to take into account two specific features of the EU budget. Firstly, the budget is exceptionally small; secondly, the structure of expenditures is extraordinarily specific. The size of the EU budget is only about 1\% of GDP (148.5 billion euro in 2013). Regarding the structure of expenditures, $57 \%$ of them are related to the allocation function and about $40 \%$ to the redistribution function, whereas only minor expenditure chapters represent macroeconomic stabilization.

The contrast between such a marginal role of joint fiscal policy and the centralised monetary policy represented by the European central bank is an important reason for vast discussion 
regarding the reform of the EU budget. Furthermore, the financial, economic and public debt crisis intensified the discussion on the necessity of a strengthening role for EU fiscal policy.

Therefore, we will now take a look at the part of this discussion that uses arguments from the theory of fiscal federalism, where, in fact, one can identify two lines of argument. A (minor) group of authors propose reforms aimed at full fiscal union in the EU, while the majority of authors suggest only a partial strengthening of the role of the EU budget. Regarding the first group, Bordo, Jonung and Markiewicz (2013) or Vallee (2014) are proponents of the approach supporting harmonization and centralization towards a full fiscal union. Bordo, Jonung and Markiewicz (2013, p. 482-483) identify five conditions for an efficient fiscal union, which can prevent risks of divergent fiscal policies: a credible commitment to a no-bailout rule, a degree of revenue and expenditure independence reflecting the preferences of the voters, a well-functioning European system of transfers in times of distress, the creation of a euro bond market serviced by taxes collected by the EU government, the ability to learn from and adapt to changing economic and political circumstances. The conclusions are based on the fiscal history of five federal states: Argentina, Brazil, Canada, Germany, and the USA.

Regarding the second group, Bargain (2013), Begg (2009), Csürös (2013), Dabrowski (2013), Hinarejos (2013) or Molnar (2012) are proponents of an approach questioning both the sense and enforceability of a fiscal union in Europe. Similarly to this paper, Hinarejos (2013) distinguishes between two models of fiscal federalism: the "surveillance model" and the "classic fiscal federalism model". Concerning the former, Member States continue to have full fiscal competence (tax revenues and allocation of sources) and the competence to conduct a general economic policy as well. The mainly corrective EU role is, in particular, to enforce fiscal discipline and prevent structural asymmetries and asymmetric shocks. On the contrary, the latter assumes a much deeper centralization in the form of an independent sphere of fiscal authority. Both the Member States and the EU have the competence to raise revenues and to provide (different kinds of) public goods. This model typically includes a version of a "transfer union" as well. Hinarejos considers the surveillance model to be a natural progression of the status quo in the EU.

Other authors, further to Musgrave and Oates, explicitly discuss the distribution of fiscal functions in the EU. Csürös (2013) says that the EU strengthened the stabilisation function (outside the EU budget) and the allocation function (of the budget) during the crisis period. Nevertheless, according to the fiscal federalism theory, the EU should further strengthen these tools of economic governance that are also relevant to tackling asymmetric shocks. In fact, Csürös claims, the new financial framework (2014-2020) has brought a reduction in the redistribution function and more restrictive conditions for the subsidy system. While Csürös states that the EU has not extended the redistribution, Bargain (2013) directly argues against it. Introducing an EU tax and transfer system, the potential gains will not be big enough to generate sufficient political support for such a reform. Instead of that, he suggests exploring other ways to improve macroeconomic stability without the redistribution of incomes. Similar to Bargain, Begg (2009) points out political economy issues describing group interests and corruption risks during the transferring of resources 
between the Member States. Besides, Begg considers the current size of the EU budget too small to be able to fulfil the redistribution function in an operative way. In addition to that, Begg mentions an ambiguity about what things flowing from the EU budget to Member States should be called distributive and what allocative. Dabrowski (2013) admits that the current integration architecture of the EU/EMU contains several elements of fiscal union (bailout facilities, fiscal rules and their surveillance, harmonization of indirect taxes). On the other hand, he states that the establishment of a common currency has, in general, been followed by neither fiscal nor political integration. Furthermore, according to Dabrowski, neither does the OCA theory provide unquestionable arguments in favour of the necessity to complement monetary integration with the centralization of fiscal resources.

Summarizing the discussion on the EU budget, which uses arguments from the theory of fiscal federalism, most authors recommend strengthening the stabilization function of public finance, usually in the form of rules and surveillance institutions (e.g., Fiscal Compact, the Six-Pack, European Semester). On the contrary, they usually refuse any intensification of the redistribution function, as intergovernmental transfers in contemporary Europe are highly unpopular. Full fiscal union in contemporary Europe is, therefore, considered to be politically unenforceable.

\section{Coordination vs. harmonization within the context of fiscal policy integration in Europe}

Section IV deals with the matter of fiscal policy integration in the current EU. Section "Fiscal policy heterogeneity in the EU" summarizes the reasons, features and consequences of persisting heterogeneity in the fiscal area in Europe, including the impact of the integration of CEE countries. Section "Tax systems and policy in the EU: harmonization, coordination and competition" then provides a case study focusing on a key area of fiscal policy - the tax system.

\section{Fiscal policy heterogeneity in the EU}

Fiscal policy has been heterogeneous to a large extent in Europe so far. The differences in fiscal policies were clearly revealed due to the global financial crisis and its aftermath. The crisis had a different impact on the particular EU states. Also, the fiscal policy reactions were dissimilar across EU countries. Whereas some countries (the Czech Republic or Spain) attempted to slow down or prevent rising fiscal deficits by means of restrictive policies, other countries (Sweden or Poland) reacted with fiscal expansion. As stated by Kočenda, Kutan, and Yigit (2008), fiscal policies were largely heterogeneous without significant progress in convergence before the crises in Europe. Using some alternative measures, their paper observes poor progress in fiscal convergence and a lack of fiscal discipline in general across the EU states. Furthermore, the new EU countries are shown as relatively more fiscally disciplined than the EU15.

Regarding the current state of macroeconomic policy harmonization or coordination efforts in the EU, Rozmahel et al. (2013) provide some evidence of the persisting fiscal policy diversity in the EU using the multi-dimensional cluster analysis approach. In addition, 
they show that the new EU states do not harmonize their monetary policy strategies and priorities to the common monetary policy conducted by the ECB. Using the average distance within clusters of the EU core, periphery and CEE countries as a measure of the internal homogeneity of the country-clusters, they examined whether the heterogeneity in the area of macroeconomic policy changes over time. Furthermore, they checked the change in heterogeneity when enlarging the core cluster by periphery, CEE countries or both to examine the contributions of both country-groups to changing heterogeneity in analysed dimensions.

Figure 2: Average distances in clusters as a measure of internal homogeneity in 2000-2012

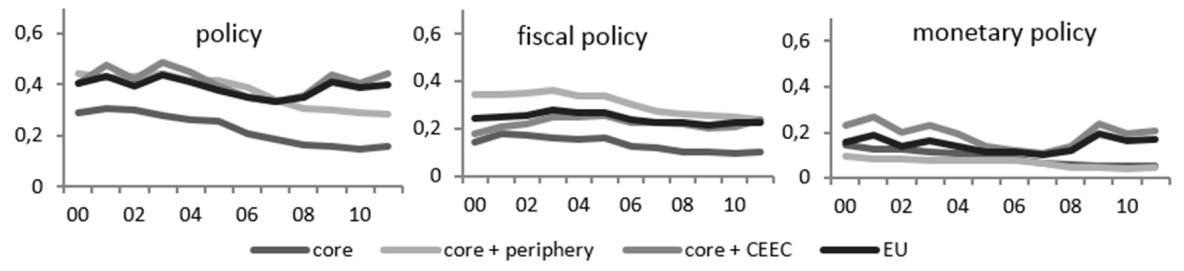

Source: Rozmahel et al. (2013)

Two indicators of monetary and fiscal policy were included in the dimension. Then the dimension was split into monetary and fiscal parts. The Monetary Policy dimension examines the internal homogeneity of clusters applying Official Lending Rates (\%) and the development of Money and Quasi Money (\% of GDP). The dimension of Fiscal policy was made using indicators of Total Government Expenditures (\% of GDP) and Implicit Tax Rate on Labour. Both fiscal measures are under the deliberate control of the autonomous national governments of the EU countries, and at the same time, these measures are neither explicitly determined by the Growth and Stability pact, nor by its actual modification in the form of the European Fiscal Compact, signed in 2012. Therefore, the inclusion of those indices aims to shed some light on fiscal and tax policy harmonization processes in the EU. The level of internal harmonisation of the macroeconomic policy conduct in the EU core countries is steadily rising, as indicated by the decreasing curve of the average internal distance within clusters. The convergence is also obvious when enlarging the core with CEE as well as Periphery countries up to 2007. Since the crisis hit in 2007/2008, CEE countries have contributed to rising policy heterogeneity within the EU, as indicated by rising curves since that time in the figure. Clear convergence tendencies among the euro area core countries are shown in the figure when splitting the indices between the fiscal and monetary dimension. The figure also indicates the clear divergence of CEE countries, since the heterogeneity of the euro area core country-cluster rises steadily when enlarged by CEECs. The peripheral countries exhibited slow progress in convergence towards the euro area core countries over the analysed period of 2000-2012. Significantly diverse monetary reactions of CEE countries from the core of the euro area during the crisis and its aftermath are shown in the figure describing the monetary policy dimension.

Considering the impacts of existing fiscal heterogeneity upon integration processes, there is still a lack of empirical literature, as noted by, for instance, Crespo-Cuaresma, Pfaffermayr, 
Amador and Keppel (2011) or Darvas, Rose, and Szapáry (2005). Darvas et al. (2005) provide evidence of a strong relation between fiscal convergence and more synchronised business cycles in their pioneering study. In addition, they also find that reduced primary deficits improve business cycle synchronisation across the OECD countries. CrespoCuaresma et al. (2011) also point out the lack of attention to fiscal policy influence on the business cycle similarity of EU countries in contemporary literature. Applying measures of the fiscal budget surplus, trade integration measures as well as instruments, they analyse the effect of fiscal policy on cyclical synchronisation in the euro area. Using also the instruments for fiscal policy measures capturing mainly the information on political determinants of fiscal stances, they determine that the fiscal deficits are identified as sources of idiosyncratic macroeconomic fluctuations in the euro area. Their results support the main findings of the study by Artis, Fidrmuc, and Scharler (2008) that identifies divergent fiscal policies and heterogeneous labour market rigidities as factors reducing business cycle synchronicity. Focusing also on the role of CEE countries, Rozmahel et al. (2014) examine the negative effect of the fiscal indiscipline and dissimilarity on business cycle correlation in the EU. An increased effect upon business cycle correlation has been observed since 2007, which the authors attribute to the influence of the global crisis. Holm-Hadulla, Hauptmeier and Rother (2012) identify a procyclical fiscal behaviour of governments that have no strict numerical expenditure rules. Concluding that countries with strict numerical expenditure rules do not have a pro-cyclical bias for their spending policy, they provide arguments for the need for rule-based restrictions to expenditure policy.

The actual heterogeneity in the fiscal area, together with the trends of rising deficits and debts in the EU, represents a significant problem for the effective and sustainable functioning of the EU and also in achieving long-term strategic goals in the economic area. Deficits limit the functioning of discretionary fiscal policy as a tool of adjustment in the event of the occurrence of asymmetric shock. Indebtedness is naturally costly for other EU member states that contribute to bailouts. Fiscal heterogeneity negatively affects interest rate development and might be a potential source of idiosyncratic macroeconomic fluctuations in the euro area. On the other hand, there are still arguments as to why strong harmonisation, leading to fiscal unification in terms of unified tax systems and spending policies, might not be the right solution for Europe. Fiscal policy harmonisation in this sense implies harmonisation of tax policies and also welfare states, since they are highly interrelated. The following section examines the heterogeneity factors in the area of tax policies in the EU.

\section{Tax systems and policy in the EU: harmonization, coordination and competition}

The coordination of taxation systems has been discussed in the European Union since the beginning of the integration efforts in the 1960s. Primarily, the intention was very ambitious - the aim was not tax coordination but full tax harmonization - i.e. not only structural harmonization, but also harmonization of tax rates. Nevertheless, the harmonization of tax rates proved to be extremely difficult - mainly due to the fact that it is perceived by EU Member States as an infringement of their national sovereignty. 
Naturally, pros and cons of both harmonization and coordination can be found. The need to preserve maximum fiscal autonomy should be considered the first factor working against tax harmonization in the EU because the role of national central banks in the monetary union is limited. Secondly, the different level of the tax rates set in the member states reflects the different structure of the taxation mix and specifics of individual member states, particularly in the case of those states applying a higher level of value added tax (VAT) rate. For example, in Denmark, Belgium or Spain, VAT represents a substantial part of budget revenues.

Thirdly, as Hamaekers (1993) mentions, tax competition can result in a spontaneous harmonization effect among (neighbouring) countries. It is the view of this paper that this effect is questionable. A different level of VAT tax rate has been applied in the EU since the introduction of the common system of indirect taxation and no spontaneous harmonization effect has accrued. Fourthly, there is the example of the United States; even though they represent an area with a much higher degree of integration (mainly fiscal harmonization) than the EU, the taxation systems of members of the Union differs significantly. And the existence of different taxation systems in the United States does not deform the market environment.

In addition, as Mitchell, Sikka, Christensen, Morris and Filling (2002) mention, tax competition generates a responsible tax policy with a lower tax burden for business entities, which creates a positive environment of higher economic growth. Without tax competition, the government might behave like a monopoly structure setting higher tax rates, which can discourage foreign capital.

On the other hand, there are also arguments for tax harmonization. Firstly, as Kubátová (2012) mentions, in the case of market failure, competition is not able to guarantee efficiency. For the taxpayer who does not receive an equivalent value against the paid tax, there is a lower incentive to pay tax in the country in which they use public services. Therefore, in extreme situations, this could lead to the elimination of taxation. Moreover, tax competition can result in an increase in the taxation of immobile factors (mainly work) and a decrease in the taxation of highly mobile factors (mainly capital). It also might cause an inappropriate structure of budget expenditures, as the government provides incentives, subventions and support in order to attract capital. Similarly, tax competition can lead to tax base erosion in other states and deform the effective allocation of capital and services, as Edwards and de Rugy (2002) mention.

Furthermore, as Zodrow (2003) argues, tax competition may lead to the inefficient provision of public services (the extent of redistribution programmes). Also, the existence of externalities can be considered another reason for tax harmonization. In reality, the taxation system influences the budget revenues of different countries. Bigger countries have the power to influence world prices and to improve their own exchange relations. Finally, in the area of corporate taxation, competition does not allow companies acting on the internal market to fully use the advantages that the internal market provides. Therefore, in this area, it is necessary to reach at least a certain degree of tax harmonization.

Generally, tax competition is often considered beneficial, as it creates the pressure to decrease budget expenditures. From the point of view of the EU, it could increase overall 
competitiveness. On the other hand, unrestricted and undirected tax competition in the area of mobile factors could endanger the tax revenues of EU member states. In a situation where the main aim of the tax policy in the EU is the smooth functioning of the internal market and an increase in competitiveness, not only of market subjects, but of the EU itself, we can set those criteria which should be fulfilled either by tax harmonization or by tax competition. The evaluation of tax harmonization and tax competition is stated in the following table:

Table 1: Evaluation of tax harmonization and tax competition

\begin{tabular}{|c|c|c|}
\hline Criterion & Tax harmonization & Tax competition \\
\hline Fiscal autonomy & no & yes \\
\hline Stability of budget revenues & $\begin{array}{l}\text { no - tax rate does not reflect } \\
\text { the specific of individual states }\end{array}$ & $\begin{array}{c}\text { yes - but not in countries with } \\
\text { capital outflow }\end{array}$ \\
\hline $\begin{array}{l}\text { Effectiveness of public } \\
\text { expenditures }\end{array}$ & no & yes \\
\hline $\begin{array}{l}\text { Increase in the competitiveness of } \\
\text { the market subjects }\end{array}$ & yes & $\begin{array}{l}\text { no - leads to an increase in the } \\
\text { compliance costs of taxation }\end{array}$ \\
\hline $\begin{array}{l}\text { Inappropriate structure of budget } \\
\text { expenditures }\end{array}$ & no & yes \\
\hline $\begin{array}{l}\text { Excessive taxation of immobile } \\
\text { factors }\end{array}$ & no & yes \\
\hline $\begin{array}{l}\text { Full usage of the advantages } \\
\text { connected with the internal market }\end{array}$ & yes & no \\
\hline Effective source allocation & yes & no \\
\hline $\begin{array}{l}\text { Existence of asymmetric } \\
\text { information }\end{array}$ & no & yes \\
\hline $\begin{array}{l}\text { A difference in nominal and } \\
\text { effective tax rate }\end{array}$ & no & yes \\
\hline Tax rate & higher & lower \\
\hline Economic growth & lower & higher \\
\hline
\end{tabular}

Source: Authors

\section{Conclusion}

This paper addresses the question of whether EU policies should head towards autonomy, coordination or harmonization. Taking the path dependence effect into consideration, it is the authors' opinion that Europe has gone too far in its integration process to be able to continue with policies being fully under the competences of individual member countries. A substantial change in these trends would incur almost prohibitive costs. Furthermore, the high level of monetary unification, having already been accomplished, to a great extent excludes fully autonomous fiscal policies. On the other hand, Europe 
is still too heterogeneous and it will remain so in future, simply because of the fact that people in Ireland, Hungary, Portugal or Sweden are different, have a distinct mentality, culture, traditions, social relations and ways of thinking. Therefore, a goal-directed topdown harmonization path towards full unification is neither reasonable nor realistic. On the contrary, it could even be contradictory, since it could increase antipathy towards the European integration process itself.

For these reasons, we propose that the EU should officially declare that, within the European integration process, there no goal to achieve absolute harmonization in all areas; an adequate level of coordination in each particular policy area should be sufficient. What does this mean in the fiscal area discussed in this paper? Fiscal union in the current form of the EU is neither politically enforceable, nor economically rational. On the other hand, in order to maintain the viability of the European integration process, it is necessary to reduce behaviour with features of moral hazard and free ride and strengthen joint responsibility for the fiscal development of public finances in the EU.

Regarding recent efforts to strengthen coordination and discipline in the fiscal area, e.g., by modifying the Stability and Growth Pact (SGP) with the Fiscal Compact, the SixPack, European Semester and other economic policy coordination initiatives in the EU, one can hardly assume to what extent fiscal policy will converge and what will be the influence on fiscal discipline in the upcoming future. Unfortunately, adherence to most of the directives and initiatives is binding mostly due to sanctions of a financial nature, or they are not binding at all, since they are just recommendations. This is one of the main critical arguments against the SGP in literature (Annett, Decressin and Deppler, 2005; De Haan, Berger and Jansen, 2003; De Grauwe, 2012). In particular, the exercise of financial sanctions against countries with deficit of public finance makes their budgetary problems worse. In addition, these financial sanctions can be easily interpreted by national politicians in the sense that the EU is the cause of, or an accomplice to, a country's budgetary problems. As a consequence, doubts naturally arise regarding the better functioning of the new schemes. Therefore, the paper suggests implementing additional sanctions, which are of a more institutional nature. In this sense, we propose (re-)considering the following measures:

- a partial, temporary limitation of a country's voting right at particular summits, councils, meetings of ECOFIN, Economic and Financial Committee, Economic Policy Committee, etc.

- public hearings in national parliaments in those countries which break the joint provisions on fiscal discipline, moreover, under the attendance of representatives of a certain EU economic body.

These two proposals head towards creating an uncomfortable setting for national politicians who are responsible for breaches of common agreements. The former means the symbolic limitation of politicians' power, while the latter should attract more attention in the country's media to a particular problem, and therefore also increase pressure on national politicians. Being willing to be more courageous and, in the authors' view, more efficient in terms of the impact on public monitoring of fiscal responsibility, it is possible 
to deal with such alternatives as a deduction of points in the UEFA and other events of a similar importance.

Besides the matter of joint responsibility, we point out the open coordination method as an approach which is in accord with this paper's line of argumentation. We are in agreement with Zeitlin (2005) that it may be a sustainable alternative path between a fragmented Europe and a European super state. The open coordination method could be suitable both for the fiscal area and for the considerably heterogeneous areas of welfare states and social policies, which are other fundamental obstacles to formation of a fiscal union in contemporary European Union.

\section{Acknowledgements}

This paper is a part of research project WWWforEurope No. 290647 within the Seventh Framework Programme supported financially by the European Commission.

\section{References}

Allen, F., Carletti, E. and Gray, J. (Eds.). (2013). Political, Fiscal and Banking Union in the Eurozone? (1st ed). Philadelphia: FIC Press.

Annett, A., Decressin, J. and Deppler, M. (2005). Reforming the stability and growth pact. IMF Policy Discussion Paper 05/2.

Aiginger, K. (2013). A new strategy for the European periphery. WWWforEurope Policy Paper, No. 1.

Arthur, W. B. (1989). Competing Technologies, Increasing Returns, and Lock-In by Historical Events. The Economic Journal, 99(394), 116-131.

Artis, M. J., Fidrmuc, J. and Scharler, J. (2008). The transmission of business cycles Implications for EMU enlargement. The Economics of Transition, 16(3), 559-582.

Bargain, O. (2013). Fiscal Union in Europe? Redistributive and Stabilizing Effects of a European Tax-Benefit System and Fiscal Equalization Mechanism. Economic Policy, 28(75), 375-415.

Beetsma, R. and Giuliodori, M. (2010). The Macroeconomic Costs and Benefits of the EMU and Other Monetary Unions: An Overview of Recent Research. Journal of Economic Literature, 48(3), 603-641.

Begg, I. (2009). Fiscal Federalism, Subsidiarity and the EU Budget Review. Swedish Institute for European Policy Studies Report 2009:1.

Bénassy-Quéré, A., Trannoy, A. and Wolff, G. G. (2014). Tax harmonization in Europe: Moving forward. Les notes du conseil d'analyse économique, 2014(1), 1-11.

Bird, R. M. and Ebel, R. D. (2007). Fiscal Fragmentation in Decentralized Countries: Subsidiarity, Solidarity and Asymmetry (1st ed). Northampton: Edward Elgar Pub.

Bordo, M. D., Jonung, L. and Markiewicz, A. (2013). A Fiscal Union for the Euro: Some Lessons from History. CESifo Economic Studies, 59(3), 449-488.

Burda, M. and Wyplosz, Ch. (2012). Macroeconomics: A European Text (6th ed). Oxford: Oxford University Press. 
Business Insider. (2015). Here's What A 'Grexit' Would Cost Europe. Retrieved February 6, 2015, from http://www.businessinsider.com/afp-weighing-the-costs-for-europe-if-greeceexits-the-euro-2015-1.

Calderoni, F. (2010). Organized Crime Legislation in the European Union: Harmonization and Approximation of Criminal Law, National Legislations and the EU Framework Decision on the Fight Against Organized Crime (1st ed). Heidelberg: Springer Science \& Business Media.

Clement-Wilz, L. (2014). Reforming Europe Transformation of EU Competence in the Field of Economics with the Anti-crisis Measures. Revue de L'OFCE, Debates and policies, No. 134: 99-110.

Crespo-Cuaresma, J., Pfaffermayr, M., Amador, O. F. and Keppel, C. (2011). Macroeconomic Aspects of European Integration: Fiscal Policy, Trade Integration and the European Business Cycle. FIW Research Report Series, 2010/11, 4.

Csürös, G. (2013). Characteristics, functions and changes (?) of EU budget. Juridical Current, 16(4), 92-107.

Dabrowski, M. (2013). Fiscal or Bailout Union: Where Is the EU/EMU's Fiscal Integration Heading? CASE Network Studies, 2013(466), 1-34.

Darvas, Z., Rose, A. K. and Szapáry, G. (2005). Fiscal Divergence and Business Cycle Synchronization: Irresponsibility is Idiosyncratic. NBER Working Paper 11580.

Darvas, Z. and Wolff, G. B. (2013). Should Non-Euro Area Countries Join the Single Supervisory Mechanism? DANUBE: Law and Economics Review, 4(2), 141-163.

David, P. A. (1985). Clio and the Economics of QWERTY. American Economic Review, 75(2), 332-337.

De Haan, J., Berger, H. and Jansen, D. J. (2003). The end of the Stability and Growth Pact? CESifo Working Paper 1093.

De Grauwe, P. (2012). Economics of Monetary Union (9th ed). Oxford: Oxford University Press.

Edwards, Ch. and de Rugy, V. (2002). International Tax Competition: A 21st-Century Restraint on Government. Cato Institute Policy Analysis, 431.

Faria, A. G. A. (1995). Tax coordination and harmonization. In: Shone, P. (Ed.), Tax policy Handbook (pp. 229-234). Washington: International Monetary Fund.

Faure, M. D. (2000). The Harmonization, Codification and Integration of Environmental Law: A Search for Definition. European Environmental Law Review, 9(6), 174-182.

Fernández-de-Córdoba, G. and Torres, J. L. (2012). Fiscal Harmonization in the European Union with Public Inputs. Economic Modelling, 29(5), 2024-2034.

Financial Times. (2015). Size of Greece's debt limits scope for solutions. Retrieved February 6, 2015, from http://www.ft.com/cms/s/0/c133ac38-981b-11e4-b4be-00144feabdc0.html.

Gabrisch, H. (2011). A Macroeconomist's View on EU Governance Reform: Why and How to Establish Policy Coordination? Economic Annals, 56(191), 69-88.

Gabrisch, H. and Staehr, K. (2014). The Euro Plus Pact: Cost Competitiveness and External Capital Flows in the EU Countries. WWWforEurope Policy Paper, No. 15. 
Garcia, E. C., Pabsdorf, M. N. and Mihi-Ramirez, A. (2013). Fiscal Harmonization and Economic Integration in the European Union. Engineering Economics, 24(1), 44-51. Gelauff, G., Grillo, I. and Lejour, A. (Eds.). (2008). Subsidiarity and Economic Reform in Europe (1st ed). Heidelberg: Springer Science \& Business Media.

Giurescu, D. and Vasilescu, L. G. (2006). European Integration: Macroeconomic Coordination Risks. Annals of University of Petroşani, 6, 91-96.

Gullo, D. (2013). The uncertain journey towards fiscal harmonization. Retrieved February 6, 2015, from http://www.aspeninstitute.it/aspenia-online/article/uncertain-journeytowards-fiscal-harmonization.

Hamaekers, H. (1993). Fiscal Sovereignty and Tax Harmonization. European taxation: official journal of the Confédération Fiscale Européenne, 33(1), 25-27.

Hinarejos, A. (2013). Fiscal Federalism in the European Union: Evolution and Future Choices for EMU. Common Market Law Review, 50(6), 1621-1642.

Holm-Hadulla, F., Hauptmeier, S. and Rother, P. (2012). The impact of expenditure rules on budgetary discipline over the cycle. Applied Economics, 44(25), 3287-3296.

Kapić, J. and Bašić, M. (2013). Harmonization of international financial reporting. Business Consultant / PoslovniKonsultant, 5(1), 23-27.

Kočenda, E., Kutan, A. M. and Yigit, T. M. (2008). Fiscal Convergence in the European Union. The North American Journal of Economics and Finance, 19(3), 319-330.

Köhler-Töglhofer, W. (2011). Macro Coordination under the European Semester. Monetary Policy \& the Economy, 2011(4), 59-73.

Kubátová, K. (2012). Typologizace daňových mixů v zemích OECD. Littera Scripta, 5(2), 75-82.

Lighian, E. M. (2012). Multilevel Governance and Principle of Subsidiarity in the European Union. Europolicy - Continuity and Change in European Governance, 6(1-2), 15-26.

Machová, Z. and Kotlán, I. (2013). World Tax Index: New Methodology for OECD Countries, 2000-2010. DANUBE: Law and Economics Review, 4(2), 165-179.

Mitchell, A., Sikka, P., Christensen, J., Morris, P. and Filling, S. (2002). No Accounting for Tax Havens (1st ed). Basildon: Association for Accountancy \& Business Affairs.

Molnar, M. (2012). Fiscal Consolidation: What Factors Determine the Success of Consolidation Efforts? OECD Journal: Economic Studies, 5(1), 123-149.

Mongelli, F. P. (2002). "New" views on the optimum currency area theory: what is EMU telling us? ECB Working Paper, No. 138.

Musgrave, R. A. (1959). The Theory of Public Finance (1st ed). New York: McGraw-Hill. North, D. C. (1990). Institutions, Institutional Change and Economic Performance (1st ed). Cambridge: Cambridge University Press.

Oates, W. E. (1968). The Theory of Public Finance in a Federal System. The Canadian Journal of Economics / Revue canadienne d'Economique, 1(1), 37-54.

Oates, W. E. (1972). Fiscal Federalism (1st ed). New York: Harcourt Brace Jovanovich.

Oates, W. E. (2001). Fiscal Competition or Harmonization? Some Reflections. National Tax Journal, 54(3), 507-512. 
O'Shea, T. (2007). Tax Harmonization vs. Tax Coordination in Europe: Different Views. Tax Notes International, 46(8), 811-814.

Pierson, P. (2004). Politics in Time: History, Institutions, and Social Analysis (1st ed). Princeton: Princeton University Press.

Rantala, A. (2003). Labour market flexibility and policy coordination in a monetary union. Bank of Finland Discussion Paper, 2003(11), 1-52.

Rixen, T. and Viola, L. (2009). Uses and Abuses of the Concept of Path Dependence: Notes to-ward a Clearer Theory of Institutional Change. In: International Summer School on the Logic of Self-reinforcing Processes in Organizations, Networks, and Markets, Freie Universität Berlin.

Roman, A. and Bilan, I. (2008). Appreciations concerning economic policies coordination in EMU. Annals of the University of Oradea, Economic Science Series, 17(3), 509-512.

Rozmahel, P., Grochová, L. and Litzman, M. (2014). The effect of asymmetries in fiscal policy conducts on business cycle correlation in the EU. WWWforEurope Working Paper, No. 62 .

Rozmahel, P., Kouba, L., Grochová, L. and Najman, N. (2013). Integration of Central and Eastern European Countries: Increasing EU Heterogeneity? WWWforEurope Working Paper, No. 9.

Samuels, J. M. and Piper, A. (1985). International Accounting: A Survey (1st ed). London: Croom Helm.

Schäfer, W. (2006). Harmonisation and centralisation versus subsidiarity: which should apply where? Inter economics: review of European economic policy, 46(5), 246-249.

Shikwati, J. (2012). Towards African Tax Policy: Coordination, Rationalization or Harmonization? The African Executive. Retrieved February 6, 2015, from http://www.africanexecutive.com/modules/magazine/articles.php?article $=6673$.

Stockhammer, E. (2008). Wage Flexibility or Wage Coordination? Economic Policy Implications of the Wage-Led Demand Regime in the Euro Area. PERI Working Paper Series, No. 160.

Straume, O. R. (2003). Economic integration and environmental policy coordination. Working Papers in Economics, No. 13/03, University of Bergen.

Tanzi, V. (2008). The future of fiscal federalism. European Journal of Political Economy, 24(3), 705-712.

Vallee, S. (2014). From Mutual Insurance to Fiscal Federalism: Rebuilding the Economic and Monetary Union after the Demise of the Maastricht Architecture. International Economics, 138, 49-62.

Van Aarle, B. (2013). Surveillance and Control of Fiscal Consolidation on a Supranational Level. WWWforEurope Working Paper, No. 46.

Wang, C. (2014). Accounting Standards Harmonization and Financial Statement Comparability: Evidence from Transnational Information Transfer. Journal of Accounting Research, 52(4), 955-992.

Weingast, B. (2009). Second Generation fiscal federalism: The implications of fiscal incentives. Journal of Urban Economics, 65(3), 279-293. 
Zeitlin, J. (2005). The Open Method of Coordination in Question. In: Zeitlin, J., Pochet, P., \& Magnusson, L. (Ed.), The Open Method of Coordination in Action: The European Employment and Social Inclusion Strategies (pp. 19-33). Brussels: Peter Lang. Zodrow, G. R. (2003). Tax competition and tax coordination in the European Union. International tax and public finance, 10(6), 651-671. 